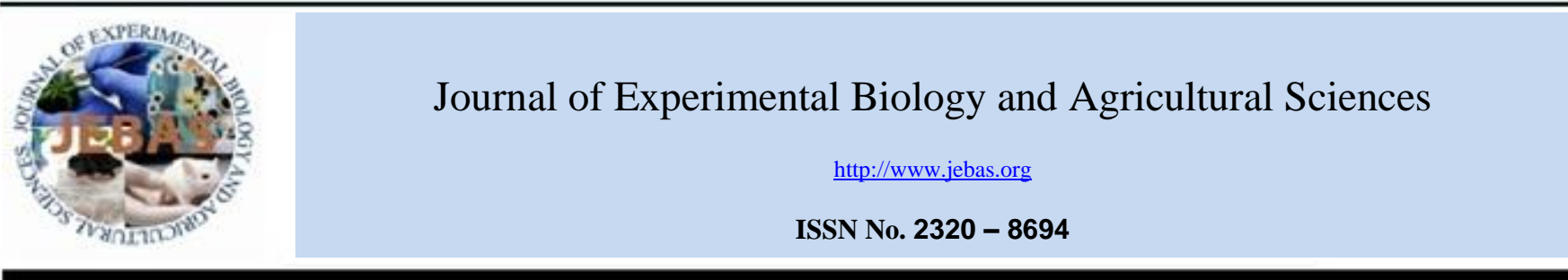

\title{
In vitro DEVELOPMENTAL STUDIES OF SELAGINELLA CILIARIS OF RAJASTHAN UNDER DIFFERENT LIGHT QUALITIES
}

\section{Kanta Meena}

Department of Botany, M. L.V. Government College, Bhilwara - 311 001, Rajasthan, India

Received - August 11, 2020; Revision - September 20, 2020; Accepted - October 16, 2020

Available Online - October 25, 2020

DOI: http://dx.doi.org/10.18006/2020.8(5).636.643

\section{KEYWORDS \\ Exine bursting \\ Megaspore germination \\ Selaginella ciliaris \\ Sporelings}

\begin{abstract}
In the current study, megaspore germination and the emergence of sporelings in vitro under different light qualities were recorded in Selaginella ciliaris (Retz.) Spring. Megaspore germination in terms of exine bursting was observed after 17 days from the date of sowing in control whereas this process under red light treatment was observed two days earlier than control. Under yellow light, it was recorded after 11days of spore sowing, which is earlier by 6 days than control while in blue light exine bursting was observed after 17 days from the date of sowing as observed in control. The emergence of sporelings was observed only in blue light treatment after 23 days of sowing. These observations indicate that yellow and red light qualities promote megaspore germination and blue light behaves as control during germination but favors the development of sporelings in this species of Selaginella occurring in Rajasthan.
\end{abstract}

* Corresponding author

E-mail: kantameenalectbotany@gmail.com (Kanta Meena)

Peer review under responsibility of Journal of Experimental Biology and Agricultural Sciences.

Production and Hosting by Horizon Publisher India [HPI] (http://www.horizonpublisherindia.in/).

All rights reserved.
All the articles published by Journal of Experimental Biology and Agricultural Sciences are licensed under a Creative Commons Attribution-NonCommercial 4.0 International License Based on a work at www.jebas.org.

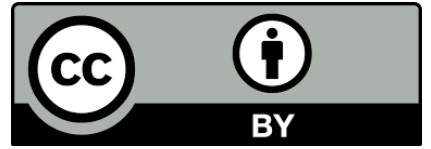




\section{Introduction}

Heterosporous genus Selaginella P. Beauv. with 700 species are worldwide in distribution (Pichi-Sermolli, 1977; Jermy, 1990). Amongst these 62 species were recorded from different biogeographic regions of India (Alston, 1945; Panigrahi \& Dixit, 1966; Panigrahi \& Dixit, 1967; Panigrahi \& Dixit, 1968; Dixit, 1984; Dixit, 1992). A detailed description of sporangial and gametophytes development in two species of Selaginella namely $S$. apus (L.) Spring and S. rupestris (L.) Spring was provided by Lyon (1901). The development of the female gametophyte in $S$. kraussiana (Kunze) A. Br. was investigated by Campbell (1902). Bruchmann (1912) studied embryology in many species of Selaginella, including S. kraussiana. Slagg (1932), during the study of microgametophyte development in $S$. kraussiana, germinated microspores on the plaster of Paris blocks. Wetmore \& Morel (1951) were able to maintain sterile cultures of megagametophytes of S. pallescens (C. Presl) Spring and S. flabellata (L.) Spring. Several workers have used artificial crossing techniques to determine the inheritance of pigmentation in Selaginella (Webster, 1979; Webster \& Tanno, 1980; Tanno \& Webster, 1982 a; Tanno \& Webster, 1982 b). Burgeff \& Filippi (1957) made inter varietal crosses between $S$. martensii Spring var. martensii and $S$. martensii var. variegata. They sowed surfacesterilized megaspores and microspores together on nutrient agar in culture tubes and after gametophytes had formed, flooded the cultures with water to achieve fertilization. After 30-40 days, sporelings appeared. Bierhorst (1964) described methods for obtaining the reproductive stages of Selaginella for classroom use. Webster (1967) reported the induction of sporelings under greenhouse and field conditions. Robert (1971a; 1971b; 1972) has provided a detailed account of mega-gametophyte development in S. kraussiana. An overview of the morphology, anatomy, and life cycle of a new model species- the lycophyte $S$. apoda (L.) Spring was provided by Schulz et al. (2010).

Rajasthan in north-west India lies between $23^{\circ} 3^{\prime}-30^{\circ} 12 \mathrm{~N}$ and $69^{\circ} 30^{\prime}-78^{\circ} 17^{\prime} \mathrm{E}$ is the largest state with an area of $3,42,239 \mathrm{sq}$ $\mathrm{km}$. Aravalli ranges, one of the oldest mountain ranges of the world, diagonally divide the state into two distinct climatic regions. The region towards the north-western side of Aravalli's is desert or semi-desert characterized by sand dunes, high wind velocity, high temperature, and thorny vegetation. The region towards the south-eastern side is a humid zone with hills of variable heights, ravines, plains, rivers, and dense forests that provides a suitable environment for the growth of pteridophytes.

Presently, four species of Selaginella namely S. ciliaris (Retz.) Spring, S. rajasthanensis Gena, Bhardwaja \& Yadav. S. repanda (Desv. ex Poir.) Spring and S. reticulata (Hook. \& Grev.) Spring are known from Rajasthan (Sharma \& Bhardwaja, 1976; Gena et al.,
1979; Dulawat \& Chaudhary, 2008; Yadav et al., 2011). Of these, $S$. ciliaris is highly restricted in its distribution and is confined, only to the northwestern part of Sitamata Wildlife Sanctuary of the state. Therefore, an attempt has been made to find out the developmental details of this fern ally of narrow distribution.

\section{Materials and Methods}

For the developmental studies spores (micro and megaspores) of $S$. ciliaris occurring in Sitamata Wildlife Sanctuary of Rajasthan were collected in August- September. Experimental studies on spore germination were conducted from November to March during the year 2013-2014.

Spores were surface sterilized with $1 \%$ sodium hypochlorite followed by repeated washing with sterilized distilled water. For spore germination and gametophyte development, sterilized spores (micro and megaspores mixed) after 48 hours of dark imbibitions were made to germinate in liquid Knop's medium (half strength) supplemented with Nitsche's trace elements using petri-dishes of $7.5 \mathrm{~cm}$ in diameter.

To provide different light qualities, white light was obtained by two fluorescent tubes fixed $60 \mathrm{~cm}$ above the petri-dishes and red light by covering petri-dishes with two layers of red gelatin paper. Similarly, blue and yellow lights were obtained by covering petri dishes with blue and yellow gelatin papers respectively. Controls for each were maintained under white light.

For each light treatment spores were sown in two sets of petridishes each containing both micro and megaspores in the culture chamber maintained at $25 \pm 2^{\circ} \mathrm{C}$. A control set was invariably included in all the experiments. The data are based on counts of 100 spores from each petri dish.

\section{Results}

\subsection{Megaspore germination under different light qualities}

During the present investigation, the author found it very difficult to study the development of male gametophyte due to its very small size and endosporic in nature. Further studies are going on to find out the details of microspore germination and microgametophyte development. Megaspore germination in terms of exine bursting and emergence of sporelings were recorded under different light treatments and the data have been presented in Table 1 and figure 1-2. Dark germination has not been observed in this species, unlike the spermatophytes wherein most of the plants seed germination takes in dark.

The data in table 1 indicate that in S. ciliaris exine bursting in red light treatment occurs 02 days earlier than control (figure $1 \mathrm{~N}-\mathrm{O}$ ). It started after 17 days of sowing in control while the germination 
Table 1 Effect of different light qualities on megaspore germination in S. ciliaris of Rajasthan ( locality -Sitamata Wildlife Sanctuary).

\begin{tabular}{|cccc|}
\hline S.No & $\begin{array}{c}\text { Light } \\
\text { qualities }\end{array}$ & Germination & $\begin{array}{c}\text { Days after } \\
\text { sowing }\end{array}$ \\
\hline 1 & $\begin{array}{c}\text { Control } \\
\text { (White light) }\end{array}$ & + & 17 \\
\hline 2 & Yellow light & + & 11 \\
\hline 3 & Red light & + & 15 \\
\hline 4 & Blue light & + & 17 \\
\hline
\end{tabular}

Table 2 Development of sporelings in S. ciliaris of Rajasthan under blue light

\begin{tabular}{|ccc|}
\hline S. No. & Developmental stages & Days after sowing \\
\hline 1 & Exine bursting & 17 \\
\hline 2 & Emergence of rhizoids & 19 \\
\hline 3 & Archegonium & 23 \\
\hline 4 & Sporophyte & 47 \\
\hline 5 & First pair of leaves & 50 \\
\hline 6 & Second pair of leaves & 63 \\
\hline 7 & Roots & 63 \\
\hline
\end{tabular}

Table 3 Percentage of sporelings of S. ciliaris with second and third pair of leaves and roots

\begin{tabular}{|ccccc|}
\hline S.No. & $\begin{array}{c}\text { Number } \\
\text { of days } \\
\text { after } \\
\text { sowing }\end{array}$ & $\begin{array}{c}\text { Percentage } \\
\text { of plants } \\
\text { with second } \\
\text { pair of leaf }\end{array}$ & $\begin{array}{c}\text { Percentage } \\
\text { of plants } \\
\text { with third } \\
\text { pair of leaf }\end{array}$ & $\begin{array}{c}\text { Percentage } \\
\text { of plants } \\
\text { with roots }\end{array}$ \\
\hline 1. & 63 & $20 \%$ & - & $20 \%$ \\
\hline 2. & 64 & $40 \%$ & - & $50 \%$ \\
\hline 3. & 65 & $50 \%$ & - & $90 \%$ \\
\hline 4. & 66 & $60 \%$ & - & - \\
\hline 5. & 67 & $80 \%$ & - & - \\
\hline 6. & 68 & $90 \%$ & $10 \%$ & - \\
\hline 7. & 69 & $100 \%$ & $20 \%$ & - \\
\hline
\end{tabular}

Table 4 Morphological features of sporelings of S. ciliaris of Rajasthan

\begin{tabular}{|cccccc|} 
S. No. & $\begin{array}{c}\text { Days } \\
\text { after } \\
\text { sowing }\end{array}$ & $\begin{array}{c}\text { Height of } \\
\text { sporelings } \\
(\mathrm{mm})\end{array}$ & $\begin{array}{c}\text { Breadth of } \\
\text { sporelings } \\
(\mathrm{mm})\end{array}$ & $\begin{array}{c}\text { Length of } \\
\text { leaves } \\
(\mathrm{mm})\end{array}$ & $\begin{array}{c}\text { Breadth of } \\
\text { leaves }(\mathrm{mm})\end{array}$ \\
\hline 1. & 58 & $0.36-2.10$ & $0.15-0.30$ & $0.30-0.63$ & $0.15-0.60$ \\
\hline 2. & 59 & $1.26-2.10$ & $0.15-0.30$ & $0.45-0.69$ & $0.18-0.63$ \\
\hline 3. & 60 & $1.20-2.10$ & $0.15-0.30$ & $0.30-0.75$ & $0.15-0.66$ \\
\hline 4. & 61 & $1.20-2.13$ & $0.15-0.30$ & $0.30-0.75$ & $0.21-0.69$ \\
\hline 5. & 62 & $1.20-2.13$ & $0.16-0.30$ & $0.30-0.75$ & $0.21-0.75$ \\
\hline 6. & 63 & $1.20-2.90$ & $0.15-0.30$ & $0.45-0.75$ & $0.15-0.75$ \\
\hline 7. & 64 & $1.20-2.25$ & $0.15-0.30$ & $0.45-0.60$ & $0.15-0.75$ \\
\hline 8. & 65 & $1.20-2.40$ & $0.15-0.30$ & $0.15-0.60$ & $0.09-0.75$ \\
\hline 9. & 66 & $1.20-2.40$ & $0.15-0.30$ & $0.36-0.60$ & $0.15-0.75$ \\
\hline
\end{tabular}

was initiated after 15 days of sowing in red light. Thus, red light slightly promotes the germination process in this species of genus Selaginella. Exine bursting under yellow light was recorded after 11days of spore sowing, which is earlier by 6 days than control (table 1, figure $1 \mathrm{E} \& \mathrm{~F}$ ). This indicates that yellow light has promotory effect on spore germination. Interestingly the exine bursting of megaspores was observed after17 days of sowing under blue light (table 1, 2, and figures $2 \mathrm{~A}-\mathrm{C}$ ) which is similar to the time taken in control (white light). Thus, blue light behaves like a control on the process of spore germination in $S$. ciliaris.

Based on these observations, it may be concluded that yellow and red light qualities promote spore germination and blue light behaves as a control in $\mathrm{S}$. ciliaris.

\subsection{Sporeling development}

Sporeling development was recorded only in blue light. No sporeling formation was observed under red and yellow light. The spore germination under blue light was found to be $90 \%$. Bulging of mega-gametophyte was observed after 23 days of the date of sowing (figure 2C). Sporelings with cotyledonary leaves (first pair) were observed after 47days from the date of sowing (figure $2 \mathrm{H}, \mathrm{I}, \mathrm{J}, \mathrm{K}, \mathrm{L}$ ). Initially, the cotyledons were adpressed laterally, and gradually they become separate from each other (figure $2 \mathrm{E}, \mathrm{F}, \mathrm{G} \mathrm{K}, \mathrm{H}, \mathrm{K}$ ). The first formed leaves were initially whitish at the time of emergence from the megaspore wall and later on these turned green in color.

The data on the percentage of sporelings with second and third pairs of leaves and roots have been presented in table 3 . $20 \%$ sporelings with the second pair of leaves were observed after 63 days of spore sowing. Interestingly, the percentage of such sporelings reached $80 \%$ after 67 days of sowing. 90\% sporelings were observed to have the second pair of leaves after 68 days of spore sowing along with $10 \%$ sporelings with the third pair of leaves after $68^{\text {th }}$ days of sowing. Thus, within a week after the emergence of cotyledonary leaves, all the sporelings were found to bear the second pair of leaves. The percentage of sporelings with the second pair of leaves was found $100 \%$ as well as $20 \%$ with third pair were observed after 69 days of sowing. The roots were observed on $20 \%$ of plants after 63 days and on $90 \%$ of plants in 65 days of spore sowing. This indicates that the development of roots is faster than the development of leaves. After 70 days in vitro de-colorization of leaves started. No branching has been observed beyond the cotyledons.

The morphological features such as height and diameter of sporelings, length, and breadth of leaves of sporelings developed under blue light exposures have been presented in table 4 . A perusal of data presented in table 4 indicates that the height of

Journal of Experimental Biology and Agricultural Sciences http://www.jebas.org 
Fig -1

WHITE LIGHT

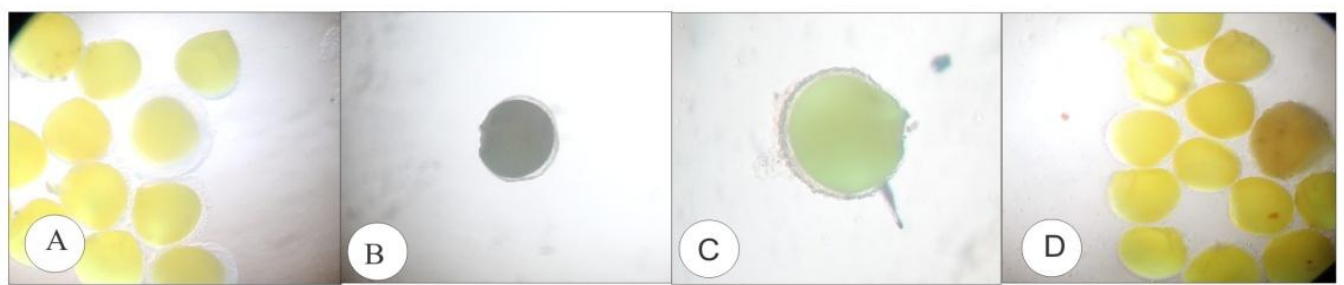

YELLOW LIGHT

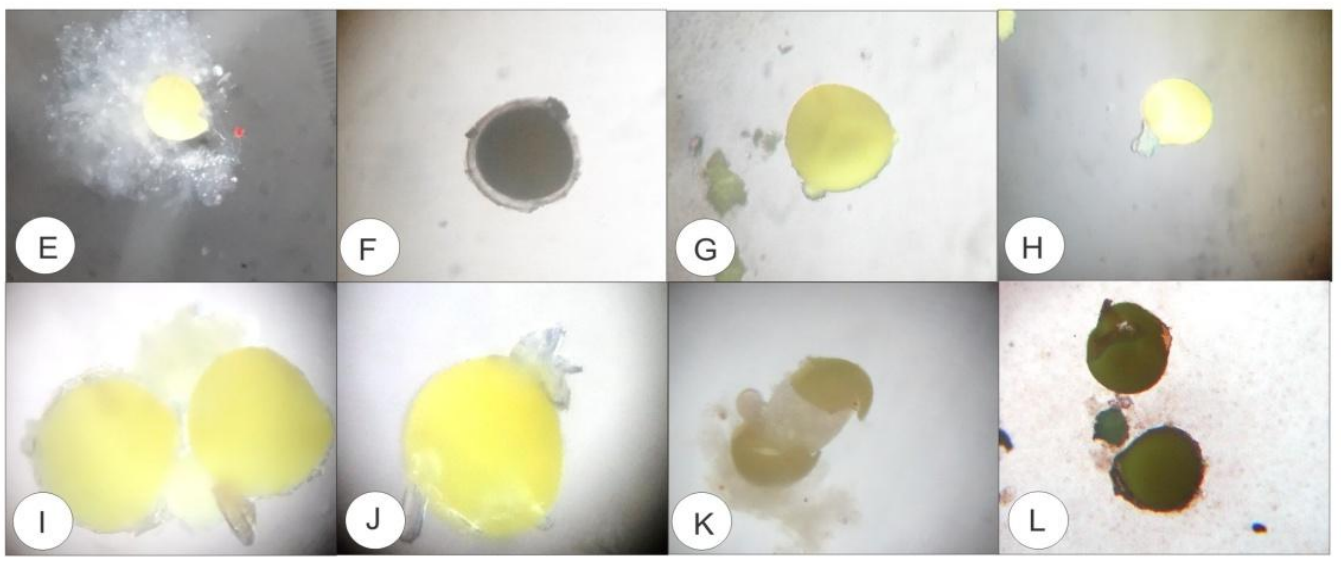

RED LIGHT

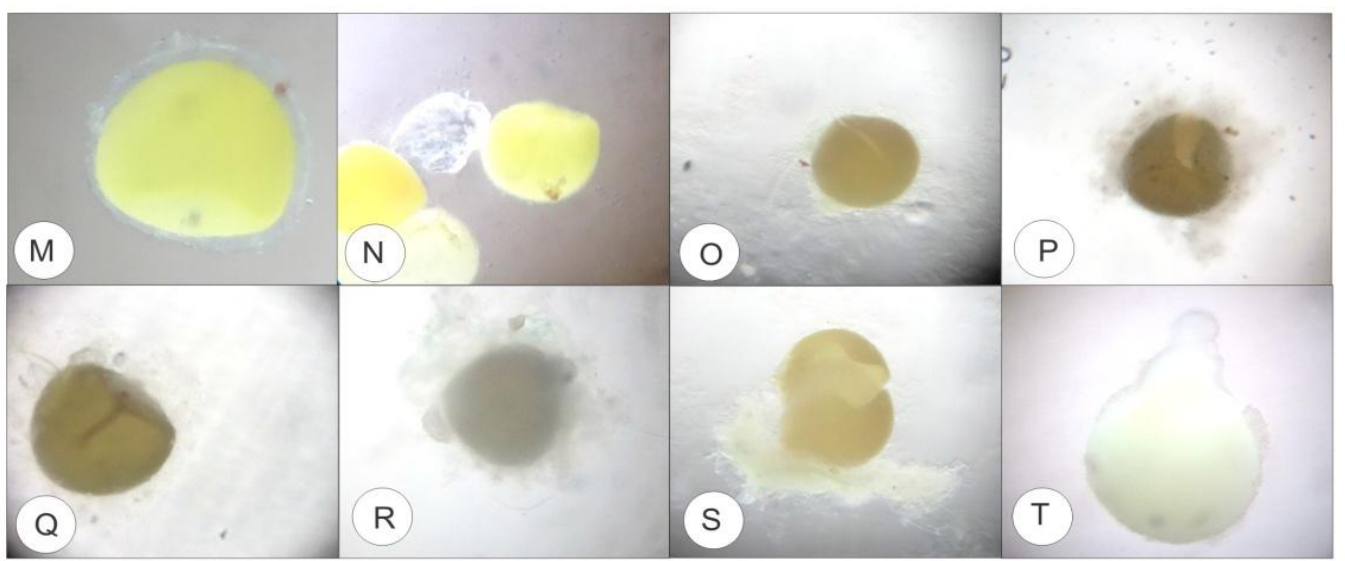

Figure 1 (A-T) In vitro Developmental studies of Selaginella ciliaris under different light qualities - Effect of white (control), yellow and red light; A-D Effect of white light (control) Exine bursting in megaspores; E-L Effect of Yellow light Exine bursting in megaspores and emergence of papilla; M-T Effect of Red light Exine bursting in megaspores and emergence of papilla

Journal of Experimental Biology and Agricultural Sciences http://www.jebas.org 
Fig.-2

\section{BLUE LIGHT}

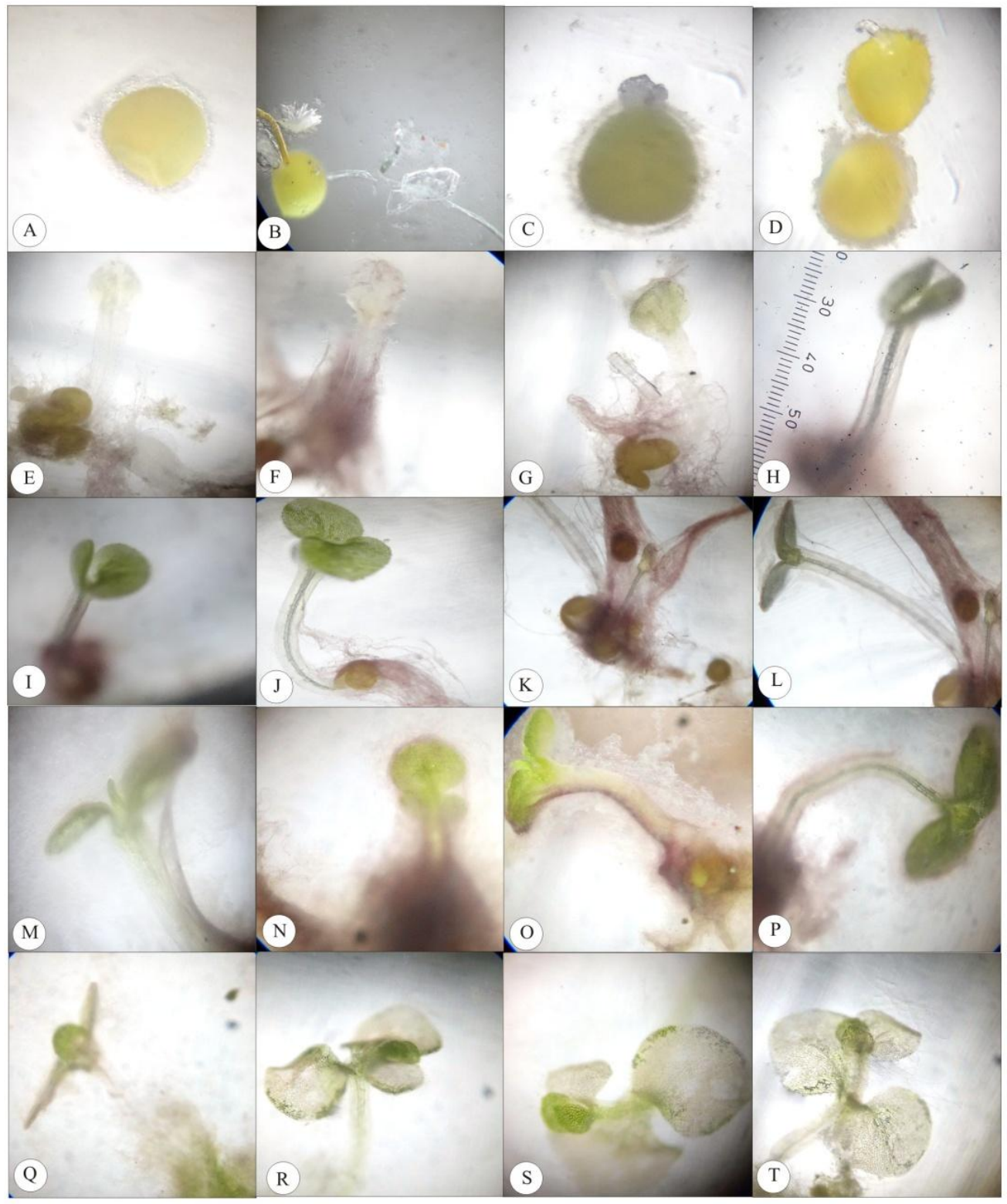

Figure 2 (A-T) In vitro Developmental studies of Selaginella ciliaris of Rajasthan under different light qualities - Effect of blue light; A-C Exine bursting in Megaspore, D - Megaspore with papilla, E-F Emergence of sporeling; G Emergence of root, H-J Sporeling with cotyledons ( $\mathrm{I}^{\text {st }}$ pair of leaves), K-L Cotyledons and subtending hypocotyle, O-P Young sporophyte with green cotyledons, hypocotyle and roots. M-Q Emergence of second pair of leaves, expanded cotyledons, R-T Emergence of third pair of leaves

Journal of Experimental Biology and Agricultural Sciences http://www.jebas.org 
sporelings varies from $0.36 \mathrm{~mm}$ to the maximum $2.4 \mathrm{~mm}$ in between 58-67 days after the date of sowing. The diameter in this period ranges from 0.15 to $0.30 \mathrm{~mm}$. Leaves of sporelings were ovate-rotund, obtuse, green $0.15 \mathrm{~mm}$ to $0.75 \mathrm{~mm}$ in length, and $0.09 \mathrm{~mm}$ to $0.75 \mathrm{~mm}$ in breadth. The vascular tissue was also visible in the sporelings.

The data on the development of lateral leaves, median leaves, and roots have been presented in table 5 . These data indicate that the development of median leaves ( $2^{\text {nd }}$ pair of leaves) take more time as only $25 \%$ of sporelings with median leaves were observed in between 61-65 days of sowing and 50\% in between 66-70 days after sowing. The leaf area of lateral leaves was generally higher which is essential for efficient trapping of light in shady habitats. The quick development of roots was observed as there were $75 \%$ sporelings with root in between 56-60 days and 95\% in between 61-65 days.

\section{Discussion and Conclusions}

The gametophytic generation of Selaginella has received far less attention than the sporophyte. The small size of the endosporic micro and megagametophytes makes them more difficult to study and gives the impression that there is little variation in gametophyte morphology throughout the genus (Webster, 1992). Several workers have tried to get male and female gametophytes as well as the sporelings of different species of Selaginella. Slagg (1932) in a study of microgametophytic development in Selaginella kraussiana, germinated microspores on the plaster of Paris blocks. A similar method for germination of both micro and megaspores was described by Bold (1967). Methods for obtaining the reproductive stages of Selaginella species have also been described by Bierhorst (1964).

Webster (1967) has described the induction of sporelings under greenhouse and field conditions. The micro and megagametophytes have also been obtained in Selaginella kraussiana through micro and megaspore germination on filter paper keeping wet with water by Webster (1979). Wetmore \& Morel (1951) germinated megaspores of S. pallescens and $S$. flabellata on nutrient agar under sterile conditions. Observations of the present study too, support these findings as during present investigations spore germination and sporelings were obtained on Knop's liquid culture medium.

The data on megaspore germination under different light qualities indicate that yellow and red light qualities promote spore germination and blue light behaves like control in S. ciliaris. Borodin (1868), Schulz (1902), and Hartt (1925) have reported that the process of spore germination is enhanced in red light and delayed in blue light. Similar results have also been reported by Tripathi (2002), Kothari (2004), Meena (2008), and Hussain (2015) in homosporous ferns. Blue light-induced inhibition suggested that phytochrome is not involved in the inhibition.
Another pigment violaxanthin, a carotenoid of wide occurrence in plants was suggested for the inhibition process. By irradiation, with blue light, the pigment is possibly converted to an inhibitory system by giving rise to an inhibitory substance. The detailed sporeling development has been observed only in S. ciliaris under blue light quality. Sporelings with the first pair of leaves were obtained after 47 days from the date of megaspore sowing. The development of the second pair of leaves (median leaves) and roots have been observed up to the 70 days from the date of sowing.

A switch over to 2D phase of gametophytes is possible only in light-grown gametophytes and involves a change in the division of cells from transverse to longitudinal plane. This reorientation of mitotic spindle requires short wavelength light below $500 \mathrm{~nm}$ (blue light) in many pteridophytes (Mohr, 1956a; Mohr, 1956b; Davis, 1968). Raghawan (1973) has reported the biplanner growth in protonema of some pteridophytes under blue light. Present investigations also, support these observations as biplanner growth and sporeling development have been observed under blue light.

\section{Acknowledgments}

Authors are grateful to Prof. T. N. Bhardwaja, Former ViceChancellor, Kota Open University, Kota, Prof. C. B. Gena, Former Vice-Chancellor, Maharaja Ganga Singh University, Bikaner and Dr. B. L. Yadav, Former, Head, Department of Botany, M.L.V. Government College, Bhilwara for critical evaluation of manuscript. Thanks to the Forest department of Sitamata Wildlife Sanctuary for their cooperation during the plant material collection. Financial assistance provided by the UGC under MRP is gratefully acknowledged.

\section{Conflict Of Interest}

Authors would hereby like to declare that there is no conflict of interests that could possibly arise.

\section{References}

Alston AHG (1945) An enumeration of the Indian species of Selaginella. Proceedings of the National Institute of Science India 11(3): 211-235.

Bierhost DW (1964) Suggestions and comments on teaching materials of the non seed-bearing vascular plants. American Biology Teacher 26: 105-107.

Bold HC (1967) A Laboratory Manual for Plant Morphology. Harper and Row New York.

Borodin J (1868) Uber die wirkung des Lichtes auf einige holhere Kryptogamen. Bulletin scientifique publié par İAcadémié impériale des sciences de Saint-Pétersbourg 12: 432-447. 
Bruchmann H (1912) Zur Embryologie der Selaginellaceen. Flora 104: $180-224$

Burgeff H, Filippi H (1957) Analyse und Erblichkeit der Panaschierung bei Selaginella martensii Spring var. variegata Hort. Biologischen Zentralblatt 76 (6)637-680.

Campbell DH (1902) Studies on the gametophyte of Selaginella. Annals of Botany 16 (63): 419-428.

Davis BD (1968) The transition from filamentous to two dimensional growth in fern gametophytes 1 The requirement for protein synthesis in gametophytes of Pteridium aquilinum. American Journal of Botany 55: 532-590.

Dixit RD (1984) A Census of the Indian pteridophytes. Flora of India, Ser 4, Botanical Survey of India, Howrah (Calcutta) India 124

Dixit RD (1992) Selaginellaceae of India. Bishen Singh Mahendra Pal Singh Dehra Dun.

Dulawat CS, Chaudhary BL (2008) Selaginella ciliaris (Retz) Spring (Selaginellaceae : Pteridophyta) A new record for Rajasthan, India. Indian Fern Journal 25: 106 - 109.

Gena CB, Bhardwaja TN, Yadav AK (1979). A new species of Selaginella from India. American Fern Journal 69(4): 119-122.

Hartt CE (1925) Conditions for germination of spores of Onociea sensibillis. Botany Gazette 79: 427-440.

Hussain S (2015) Ecophysiological studies of some seleted species of pteridophytic flora of Kumbhalgarh Wildlife Sanctuary of Rajasthan. Ph D Thesis submitted to the M D S University Ajmer, Rajasthan, India (Unpublished).

Jermy AC (1990) Selaginellaceae In: Kramer KU, Green PS (Eds.) The Families and Genera of Vascular Plants. Berlin, Spring- Verlag.

Kothari R (2004) Ecophysiological cytological and experimental studies of some Leptosporangiate ferns of Rajasthan. Ph D Thesis submitted to the M D S University Ajmer, Rajasthan, India (unpublished).

Lyon FM (1901) A study of the sporangia and gametophytes of Selaginella apus and Selaginella rupestris. Botany Gazette, xxxii, 124-141, 170-194 August-september.

Meena D (2008) Studies on distribution of Pteridophytic Flora of Bundi and Kota Districts of Rajasthan with special reference to conservational strategies. Ph D Thesis submitted to the M D S Univesity, Ajmer (unpublished).

Mohr H (1956a) Die Beeinflussung der Kelmung von farnsporen durch Licht and andere Factoren. Planta 46:534-551.
Mohr H (1956b) Die abhangigkeit des Protonemawachstums and der protonemapotariatat bie farnen von Licht. Planta 47:127-158.

Panigrahi G, Dixit RD (1968) Studies in the systematics of Indian Selaginella- I Proceedings National Institute of Science India 34 : 191-209.

Panigrahi G, Dixit RD (1966) Studies in the systematics of Indian Selaginella- III. Proceeding National Academy of Science India Allahabad 36 (1): 102-108.

Panigrahi G, Dixit RD (1967) Studies in the systematics of Indian Selaginella-II. Indian Botanical Society 46: 222-223.

Pichi Sermolli REG (1977) Tentamen Pteridophytorum Genera in Taxonomicum ordinem redigendi. Webbia. 31 (2): 313-512.

Raghawan V (1973) Blue light interference in the phytochrome controlled germunation of the spores of Cheilanthes farinose. Plant Physiology 51: 306-311.

Robert D (1971a) Le gametophyte femelle de Selaginella kraussiana (Kunze) A Br I. Organisation générale de la mégaspore Le diaphragme et l'en- dospore Les réserves Revue de Cytologie et de Biologie Végetales 34:93-16.

Robert D (1971 b) Le gamétophyte femelle de Selaginella kraussiana (Kunze) A Br II. Organisation histologique du tissu reproducteur et principaux aspects de la dédifférenciation cellulaire préparatoire a l'oogenese. Revue de Cytologie et de Biologie Végetales 34: 189-232.

Robert D (1972) Le gamétophyte femelle de Selaginella kraussiana (Kunze) A Br III. Ultrastructure et développement des archégones. Revue de Cytologie et de Biologie Végetales 35: 165-242.

Schulz C, Little DP, Stevenson DW, Bauer D, Moloney C, Stützel $\mathrm{T}$ (2010) An overview of the morphology, anatomy and life cycle of a new model species: the lycophyte Selaginella apoda (L.) Spring. International Journal of Plant Sciences 171(7): 693-712.

Schulz N (1902) Usber die Einwirkung des lichtes auf die Keimungsfashigkeit der sporen der Moose Farne und Schachtelhalme Beih Bot Contrabl 11:81-97.

Sharma OP, Bhardwaja TN 1976 Selaginella in Rajasthan India. Fern Gazette $11: 268$

Slagg RA (1932) The gametophytes of Selaginella kraussiana I. The microgametophyte American Journal of Botany 19 (2): 106-127.

Tanno JA, Webster TR (1982a) Variegation in Selaginella martensii f albovariegata I. Expression and inheritance. Canadian Journal of Botany 60: 2375-2383. 
Tanno JA, Webster TR (1982b) Variegation in Selaginella martensii $f$ albovariegata II. Plastid structure in mature leaves. Canadian Journal of Botany 60: 2384-2393.

Tripathi MK (2002) Micro-morphological and experimental studies of some selected ferns and fern allies of Rajasthan. Ph D Thesis submitted to the M D S University Ajmer, Rajasthan (unpublished).

Webster TR (1967) Induction of Selaginella sporelings under greenhouse and field conditions. American Fern Journal 57 161-166.

Webster TR (1979) An artificial crossing technique for Selaginella. American Fern Journal 69 (1): 9-13.
Webster TR (1992) Developmental problems in Selaginella (Selaginellaceae) in an evolutionary context. Annals of Missouri Botanical Garden 79: 632-647.

Webster TR, Tanno J A (1980) Inheritance of pigment deficiencies and ultrastructural defects in plastids of Selaginella kraussiana var aurea. Canadian Journal of Botany 58: 1929-1937.

Wetmore RH, Morel G (1951) Sur la culture du gamétophyte de Selaginelle Compt Rends Hebd Séances. Academy of Science 233: 430-431.

Yadav BL, Meena KL, Meena K, Hussain S (2011) Selaginella reticulata (Hook. and Grev.) Spring (Selaginellaceae) - a new record to the pteridophytic flora of Rajasthan, North-Western India. Journal Bombay Natural History Society 108 (3): 239 - 241. 